\title{
超高温ガスタービン用先進高温材料の開発と今後の課題
}

\author{
新田明人
}

財団法人電力中央研究所狛汇研究所

J. Japan Inst. Metals, Vol. 64, No. 11 (2000), pp. 958-964

Special lssue on Advanced High Temperature Materials

(C) 2000 The Japan Institute of Metals

\section{Current Status and Future Work in the Development of Advanced Materials for Gas Turbine Components used at Very High Temperatures}

\begin{abstract}
Akito Nitta
Komae Research Laboratory, Central Research Institute of Electric Power Industry (CRIEPI), Komae 201-8511

Increased turbine inlet temperature (TIT) leads to improvement in the thermal efficiency of gas turbines. At present, Japanese national projects for the development of high-temperature gas turbines with a TIT of $1700^{\circ} \mathrm{C}$ are being pursued from the perspective of global environmental preservation, so as to reduce the emission of greenhouse gases such as carbon dioxide. One of the most important aspects of these projects is the development of materials for application in very high temperature components such as blades and vanes in gas turbines. This paper describes the current situation and future plans with respect to development of such materials by means of a review of the status of Japanese national projects.
\end{abstract}

(Received June 13, 2000; Accepted September 18, 2000)

Keywords: gas turbine, high temperature, materials development, nickel-based superalloy, single crystal, intermetallic compound, ceramic matrix composite, carbon/carbon composite, thermal barrier coating, environmental barrier coating, materials evaluation, steam oxidation

\section{1. は じめに}

1997年12月に京都で開催された気候変動枠組条約第 3 回 締約国会議 $(\mathrm{COP} 3)$ Kおいて, $\mathrm{CO}_{2}$ などの温室効果ガスを 2008-2012年の期間内に，基準年(1990年)レベルに比し， 先進国全体で5\%，わが国は6\%削減するといら数值目標が 合意された。しかし，わが国の $\mathrm{CO}_{2}$ 排出量は1997年，1998 年と連続して前年比で減少したが，1998年時点で既に1990 年度に比し $6 \%$ 増大している。

このよらな現状のもとで，環境負荷の小さいェネルギーの 導入が必要とされているが，水素は然燒しても水しかできず 環境負荷が最も小さいことから，父の導入・利用抾大への期 待は大きく, わが国では, ニューサンシャイン計画の一環と して，水素利用国際クリーンエネルギーシステム技術(WENET : World Energy NETwork) 計画が1993年度から推進 されている. その目的は, 世界的に偏在する水力, 太陽光, 風力等の再生可能な自然エネルギーを水素に転換し, 発電・ 輸送用燃料・都市ガス等に幅広く利用するための技術開発を 行らことである. 現在, 本プロジェクトは1999年度より5 力年計画の第II期に入っているが，第 I 期(1993～1998年度) では，最大規模の水素利用技術として氷素燃焼タービンを 揭げ，タービン入口温度 (TIT : Turbine Inlet Temperature) $1700^{\circ} \mathrm{C}$ の下で, 発電所の所内動力分を含まない熱効率(発電 端効率)として60\%以上を達成することを目標に要素技術の 研究開発が進められた
し，早期に高効率ガスタービンの実現を図るため，燃料を水 素からメタン(液化天然ガス: LNG)に変光た二酸化炭素回 收対応クローズド型高效率ガスタービンの研究開発が1999 年度より 5 力年計画で進められている3)。この場合も, 水素 燃焼タービンと同様, TIT $1700^{\circ} \mathrm{C}$, 発電端効率 $60 \%$ 以上を 目標としている。因みに，わが国で1999年 7 月に運転が開

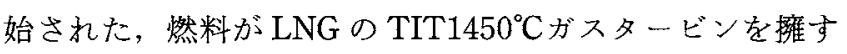
る複合発電プラント (出力 $805 \mathrm{MW}$ ) は, 所内動力分も含む 総合熱効率として50.6\%を記録した4)。これにより，従来の LNG 楚き火力プラントに比べ，燃料費の節減による経済的 効果とともに， $\mathrm{CO}_{2}$ 排出量を約 $22 \%$ 低減できるものと見込

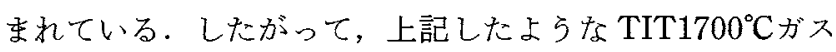
タービンが実現されれげ，その経済ならびに環境保全上の効 果は極めて大きいと言える。

このように高効率化を目指す超高温がスタービンの高温部 品には，冷却構造あるいは無冷却構造のいずれる採用する場 合にも，それぞれの構造に適合する超高温材料を適用する必 要がある。そのため，これらのプロジェクトに括重要な 技術課題の一つとして, タービンの高温化・高性能化に不可 欠な超高温材料の開発が挙げられる。

以下では，WE-NET 計画の第 I 期のなかで行ってきた， 水素燃焼タービン用超高蕰材料の研究開発の内容扎よび成果 について紹介するとともに，二酸化炭素回収対応クローズド 型高效率ガスタービンのプロジェクトにも言及し, 超高温材 料に関わる今後の課題について述べる. 


\section{WE-NET 第 I 期における超高温材料の研究 開発5,6)}

\section{1 研究開発目標}

水素然烇タービンの開発に不可欠な技術課題の一のである 超高温材料技術については， $2000^{\circ} \mathrm{C}$ 温度条件下で，既存 材料の改良や革新により，水素然烇タービン部品への応用に 必要な超高温材料を明らかにするため，各種材料の加工技 術, 材料特性評価ならびに構造設計適用の基礎的検討を行う

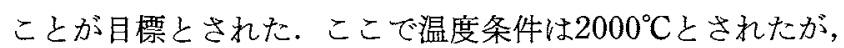
これは，TIT $1700^{\circ} \mathrm{C}$ と壳ども燃焼がス温度は場所により その上下 $200 \sim 300^{\circ} \mathrm{C}$ 程度に分布することから，材料の使用 環境温度に裕度を持たせるためである。

\section{2 研究開発成果}

\subsection{1 単結晶超合金・繊維強化セラミックスを用いたハイ} ブリッド冷却動翼の開発

Fig. 15)にハイブリッド冷却動翼の概念を示す。これは耐 熱衝撃に優れ，かつ薄いフォームの成形ならびに冷却孔の形 成が可能な軽量の耐蓺材料である䋐維強化セラミックス (FRC: Fiber Reinforced Ceramics)を断熱層兼高性能な冷却 層として用い，TIT の高温化に対応しょうとするものであ る。また，強度を受け持つ支柱部には高温破壊の起点となる 結晶粒界を排した単結晶 (SC: Single Crystal) 超合金を用い ることで，より一層の高強度(高耐熱)化を図るものである.

ところで，タービン翼の冷却効率 $\eta$ は然焼ガス温度を $T_{\mathrm{g}}$, 材料温度を $T_{\mathrm{m}}$, 冷却某体 (ここでは, 水蒸気) 温度を $T_{\mathrm{c}}$ と すると，次式で定義される。

$$
\eta=\left(T_{\mathrm{g}}-T_{\mathrm{m}}\right) /\left(T_{\mathrm{g}}-T_{\mathrm{c}}\right)
$$

今, $\mathrm{SC}$ 支柱部と $\mathrm{FRC}$ 翼面から成るハイブリッド構造に対 し，それぞれの冷却效率 $\eta_{\mathrm{SC}}$ 执よび $\eta_{\mathrm{FRC}}$ をパラメータとし て伝熱計算を行うと Fig. 25)のよら火なる。これから， $T_{\mathrm{g}}$ $=2000^{\circ} \mathrm{C}, T_{\mathrm{c}}=600^{\circ} \mathrm{C}$ とし, それぞれの冷却効率を現状レへ

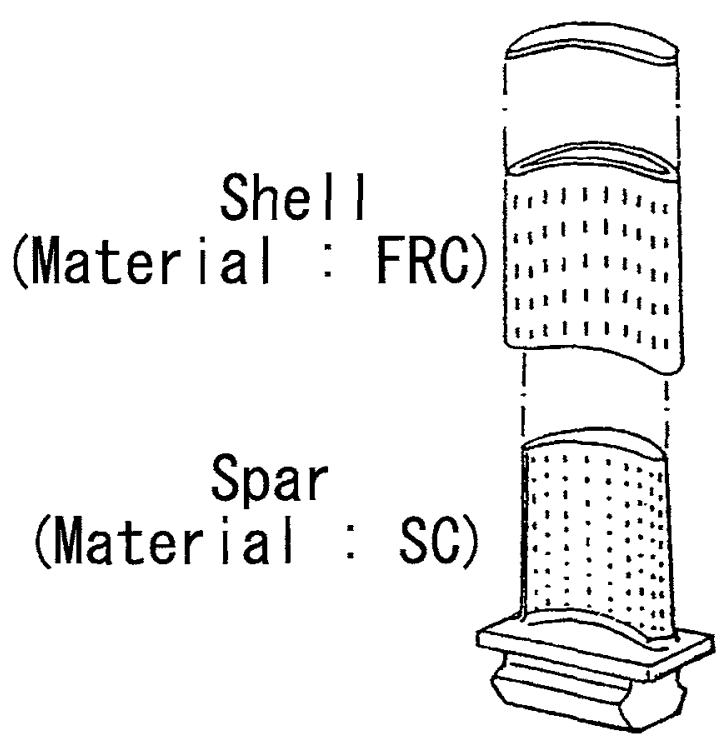

Fig. 1 Conceptual drawing of a hybrid blade structure.

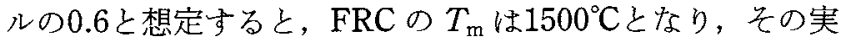
現は現状の FRC の耐熱性ではかなり困難であると考光られ るが，冷却効率が0.7亿向上すれば，FRCの $T_{\mathrm{m}}$ は $1300^{\circ} \mathrm{C}$ と なり，実現の可能性がある。

そこで，SC 超合金については，承素・酸素然焼環境が比 較的マイルドで耐食性の向上はさ汪ど必要ないと考光, 国産 $\mathrm{SC}$ 超合金 TMS63(Ni-6.9Cr-7.5Mo-5.8Al-8.4Ta)をべース に耐食性の向上とクリープ強度の低下をもたらす合金元素の Crを無添加として強度の改善を狙った合金が開発された。 その結果，開発 SC 超合金 95-Mod. D(Ni-6Mo-4.8W-

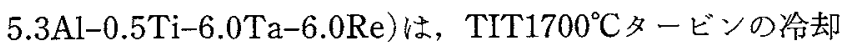
翼用候補材料である米国開発の第 2 世代 SC 超合金 CMSX4 と比較し，Fig. $3^{5)}$ に示すように，注涪同等以上の強度特

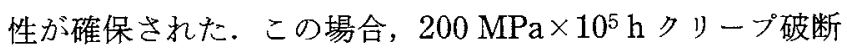
強度に対する耐用温度は約 $880^{\circ} \mathrm{C}$ なり, Fig. 2 から, FRC のクを0.7程度にできれば，ハイブッッド構造の成立性がう かがわれる。な叔， $1100^{\circ} \mathrm{C}, 200 \mathrm{~h}$ の大気中高温酸化試験の 結果，開発合金の耐酸化性は $\mathrm{Cr}$ 含有量が 10 mass\%程度の 普通鋳造合金(InconelX-750, IN100)や 8 mass\%程度の単結 晶合金 $(\mathrm{CMSX}-2)$ と同等であることが確認された。

一方，FRCについては，泠却用小孔の分布が $20 \%$ 以下と なる成形技術の開発を進めた。その結果, 孔の面積分有が $15 \%$ となる薄肉中空状 FRCの成形が可能となり, さらに気

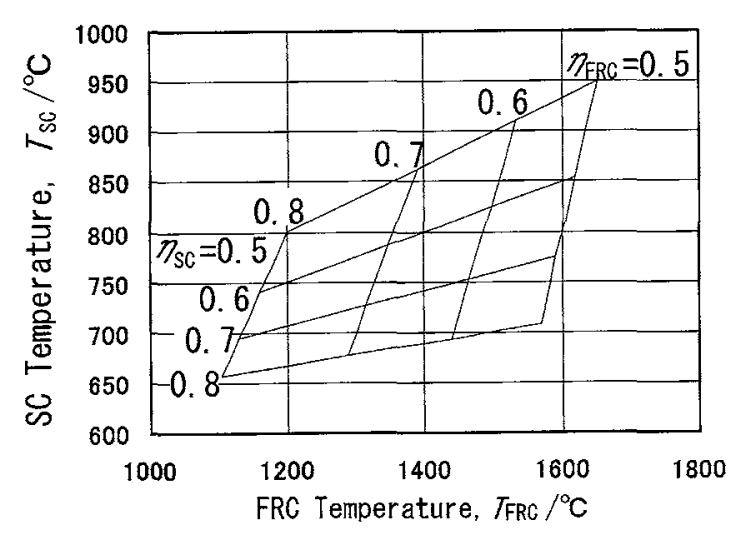

Fig. 2 Analytical result of heat transfer in the hybrid blade structure.

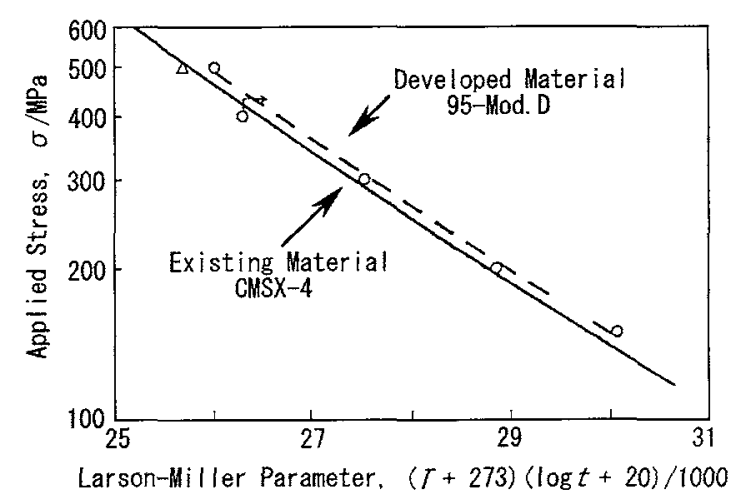

Fig. 3 Creep rupture strength of a newly developed single crystal superalloy $\left(T:\right.$ temperature $/{ }^{\circ} \mathrm{C}, t$ : time to rupture $/ \mathrm{h}$ ). 
相反応と液相含浸焼成を用い緻密化を図った。その結果，前 者では, 室温の引張強度 $304 \mathrm{MPa}$, 王縮強度 $600 \mathrm{MPa}$ が得 られ，後者では，それぞれ $427 \mathrm{MPa}, 161 \mathrm{MPa}$ とった。 今, 動翼を想定し，遠心力により FRC K生じる応力を求め ると, 約 $70 \mathrm{MPa}$ となり，いずれの強度もこの応力を上回 ることになる．

残された課題は，タービン動翼としての部材化・部品化に 向けた，複雑な冷却構造にb適用し得る中架翼鋳造技術，量 産化技術等である。

\section{2 .2 耐熱超合金冷却翼用遮熱コーティングの開発}

ここでは，Fig. 45)に示すトランスピレーション(しみ出し) 冷却構造を想定し, Fig. $5^{5}$ に示すような新概念の遮熱コ一 ティング(TBC: Thermal Barrier Coating)が考案された. すなわ方す先す耐酸化性の確保ならびに基材とセラミックス 層の線膨張係数の差により発生する熱応力の緩和のために基 材にボンドコーティング(MCrAlY 合金)を施工し，その後 加工した冷却孔に炭素を充填する. 次に，ボンドコーティン グの上にセラミックスと炭素の混合粉末を溶射した後, 炭素 を然烇・酸化させて冷却通路を形成するとともに，炭素の混 合率に応じて気孔率を制御する。このとき基材には SC 超合 金 CMSX-4，ボンドューティングには CoCrAlY 合金が選 定されるとともに，トップコーティングには，気孔率を制御

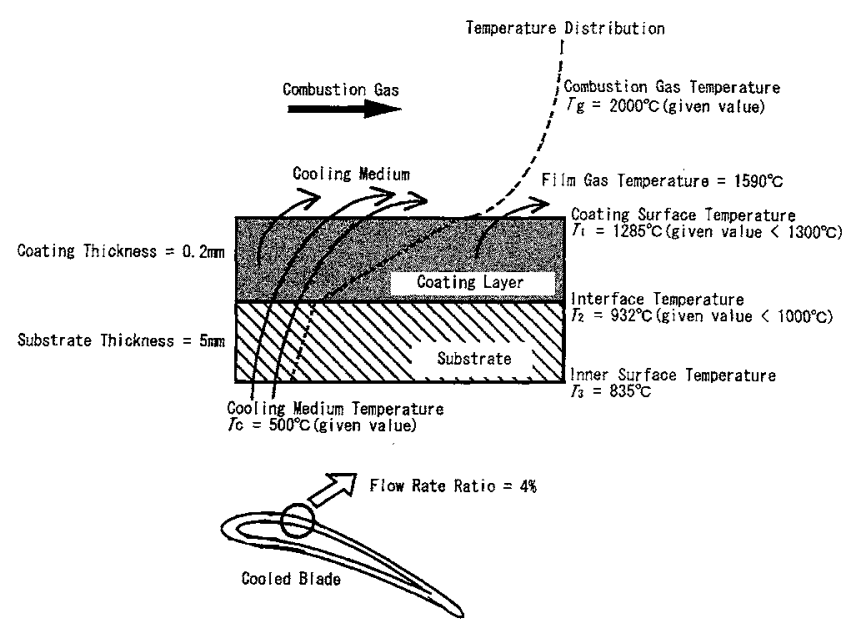

Fig. 4 Conceptual drawing of a transpiration cooling system.

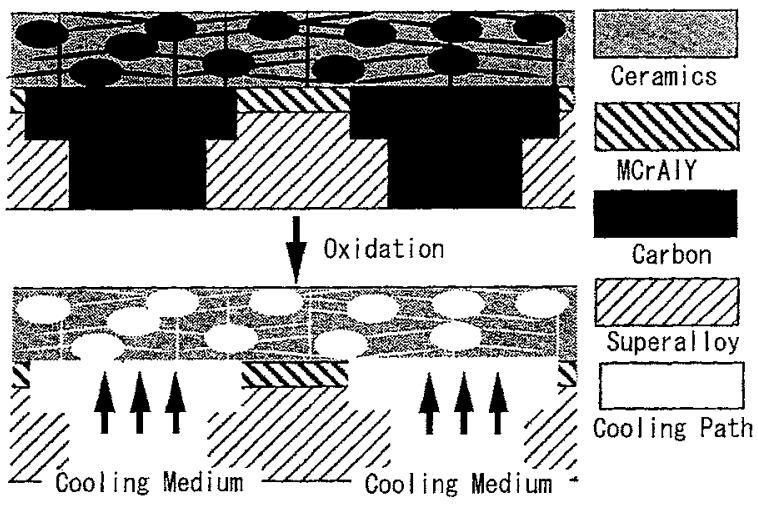

Fig. 5 Conceptual drawing of a porosity-controlled thermal barrier coating.
するため 8 mass\%イットリア $\left(\mathrm{Y}_{2} \mathrm{O}_{3}\right)$ で安定化させたジルュ ニア(YSZ: Yittria Stabilized Zirconia) 粉末持よびYSZ 粉 末(粒径 $5 \mu \mathrm{m}$ 以下の 8 mass\%YSZ)を 30 mass\%ューティン グした炭素粉末 (粒径 $5 \sim 45 \mu \mathrm{m}$ ) の混合粉末材料が選定され た。

この混合比の異なる粉本を用いて大気プラズマ溶射により 施工したコーティング皮膜の表裏の差环と空気流量を計測し た結果から，膜厚の影響を除くため次式で空気の浸透俰数に 変換し，それと差圧の関係を求めると Fig. 65)のようになる。

$$
Q=k S\left(P_{1}^{2}-P_{2}^{2}\right) /\left(2 \mu L P_{2}\right)
$$

ここで, $Q$ : 空気流量 $\left(\mathrm{cm}^{3} / \mathrm{s}\right), k:$ 浸透係数 $\left(\mathrm{cm}^{2}\right), S:$ 空気の 通過面積 $\left(\mathrm{cm}^{2}\right), \mu$ : 空気の粘度 $(\mathrm{MPa} \cdot \mathrm{s}), P_{1}$ : 空気の入口圧 力 $(\mathrm{MPa}), P_{2}$ : 空気の出口厈力 $(\mathrm{MPa}), L:$ テストピースの厚 さ $(\mathrm{cm})$ である。想定される設計条件から，冷却効率を 0.7 , 冷媒流量比を $4 \%$ とすると, 浸透係数 $k$ は $2 \times 10^{-9} \mathrm{~cm}^{2}$ 以上 でなければならない，そこで， $k$ の妥当な值として $2 \times 10^{-9}$ $\sim 3.5 \times 10^{-9} \mathrm{~cm}^{2}$ 老採ると, 圧力損失は $15.7 \sim 27.5 \mathrm{kPa}$ と なり，通常のガスタービンに特ける圧力損失 $(98 \mathrm{kPa}$ 以上) に比べて問題のない値となる。したがって，Fig. 6 の関係か ら, これを満足する YSZ ーート炭素とYSZの混合粉末の 混合比は $2: 1 \sim 1: 2$ 範囲内に最適值があることがわかっ た。

亲た，別途求めた本 TBC の熱物性值 $($ 線膨張係数, 熱伝 導率) と冷却通路面積を用いて行った伝熱計算の結果を Fig. 4 に併示しているが，この場合には，TBC表面温度执よび 界面メタル温度の設定値を満足することとなり，本 TBC 構 造が成立する可能性がうかがわれた。

残された課題は，TBC 施工条件の最適化，皮膜特性の均 質化, TBC の耐久性 - 寿命の評価, 皮膜強度と流量特性の バランス等である.

\subsection{3 弱冷却部品用金属間化合物 $\left(\mathrm{MoSi}_{2}\right)$ の開発}

種々の金属間化合物のうち，酎熱性に優れ，添加元素によ る強度改善の可能性の高い二ケイ化モリブデン $\left(\mathrm{MoSi}_{2}\right)$ が選 定され，高強度・高延性化のための組成改善には W, Al が $1600^{\circ} \mathrm{C}$ 強度向上に有効であることが明らかにされた。し かし，クリープ強度に関しては，W， $\mathrm{Al}$ にる改善効果は認

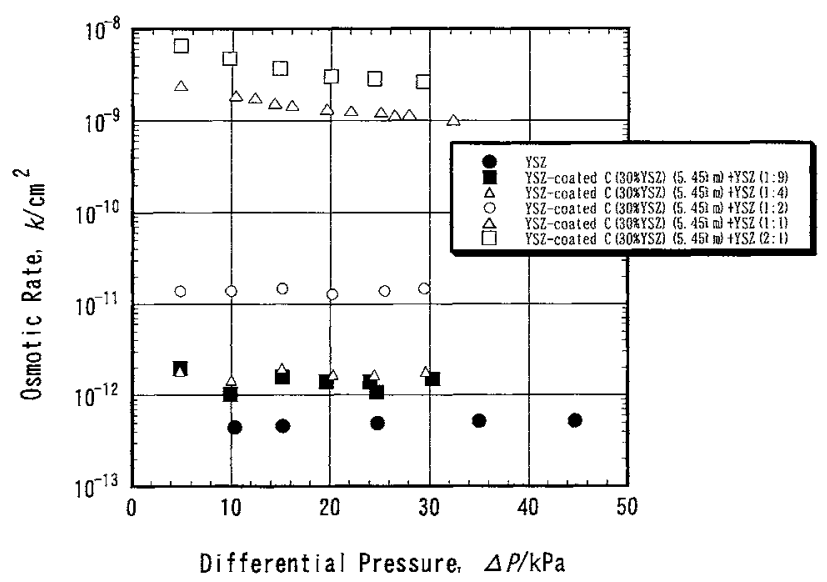

Fig. 6 Relationship between osmotic rate and differential pressure in a coating film applied by plasma spraying. 
められたが, 弱冷却部品(耐用温度 : $1600 \sim 1700^{\circ} \mathrm{C}$ )を想定 した場合には強度不足であることが判明した。その結果， $\mathrm{MoSi}_{2}$ 系の金属間化合物については，中冷却部品(1200 $\left.1400^{\circ} \mathrm{C}\right)$ としての高温強度の確保に見通しが得られたが，目 標とした弱冷却部品に対しては強度・延性の一層の向上が必 要であることから，耐熱性の確保に見通しが得られず1996 年度で研究開発を終了した。

\subsection{4 弱冷却部品用セラミック基複合材料の開発}

セラミックス自体の耐熱性から $2000^{\circ} \mathrm{C}$ 温度条件下では 弱冷却部品としての適用が期待されるセラミック基複合材料 (CMC : Ceramic Matrix Composite)については, 炭化ヶイ 素( $\mathrm{SiC})$ の基材 (マトリックス)と $\mathrm{SiC}$ 長繊維から成る CMC を対象に, 最新の高耐熱 $\mathrm{SiC}$ 繊維の採用, 繊維表面への窒 化ホウ素 $(\mathrm{BN})$ のコーティングによる界面層の高耐熱・耐環 境性の確保, 掞よびマトリックスの緻密化を図ることによ り, 気孔率执よび室温曲げ強度を従来材の $1 / 2$ および 2 倍と する目標(それぞれ $10 \%$ 以下特よび $250 \mathrm{MPa}$ 以上)に対し気 孔率約 $9 \%$ 扣よび曲げ強度 $464 \mathrm{MPa}$ となる耐熱・耐環境性 に優れた複合材料が開発された. Fig. $7^{5)}$ には，含浸・焼成 を7 回繰り返して緻密化した後に等方加圧(HIP)処理を行い 高密度化させ, 気孔率が約 $9 \%$ となった試作材の室温での 3 点曲げ試験結果を示している．また，同試作材について， $1300^{\circ} \mathrm{C}$ で $1000 \mathrm{~h}$ までと $1500^{\circ} \mathrm{C} て ゙ 100 \mathrm{~h}$ までの大気中で高温 酸化試験を行った後の室温 3 点曲げ強度も調べられた。 い ずれも傾向は同様であることから, Fig. 7 には $1300^{\circ} \mathrm{C}$ の結 果のみを示しているが, $1300^{\circ} \mathrm{C}$ の大気中で $1000 \mathrm{~h}$ 酸化させ た後も $239 \mathrm{MPa}$ の室温曲げ強度を有して扣り，その強度特 性は高温酸化時間 $200 \mathrm{~h}$ 以上で汪とんど変化していない。 た，Fig. 85)には水素燃焼タービン用に必要なコーティング の設計概念を示す．同図に扎いて，超高温水蒸気環境中で同 $\mathrm{CMC}$ 材の耐環境性を確保するための耐環境機能コーティン グには，アルミナが有効であることがわかった。一方，遮熱 性能コーティングには, 従来の TBC のトップューティング に採用されている 8 mass\% $\mathrm{YSZ}$ 安定化ジルュニア $\left(\mathrm{ZrO}_{2}\right)$ が $1100^{\circ} \mathrm{C}$ 以上で焼結し耐熱性が低下することから，その代替 材料として, $\mathrm{ZrO}_{2}$ (融点: 約 $2680^{\circ} \mathrm{C}$ ) より高融点のハフニア $\mathrm{HfO}_{2}$ (融点 : 約 $2810^{\circ} \mathrm{C}$ )が有望であることがわかった。な和, Fig. 8 に概念を示したューティングについて伝熱計算を行っ

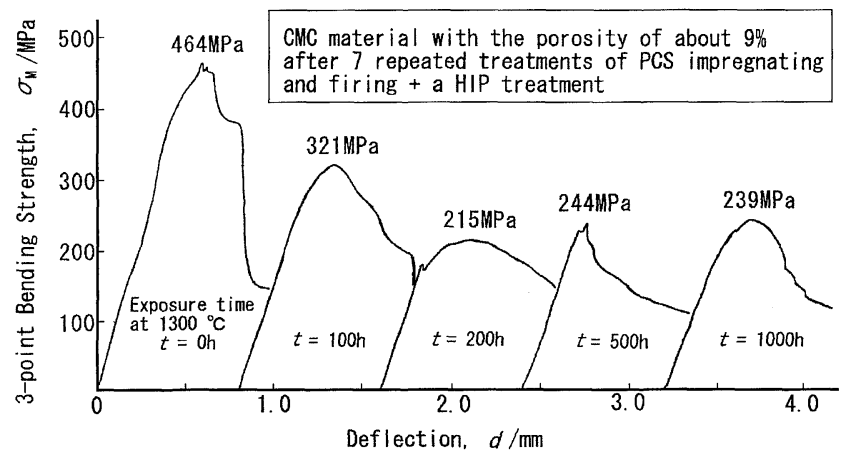

Fig. 7 Change in the bending properties of CMC material at room temperature after long term exposure in a $1300^{\circ} \mathrm{C}$ air environment.
た結果, 基材表面の耐用温度を $1500^{\circ} \mathrm{C}$ 以下をするは, 遮 熱コーティング層の厚さは $0.3 \mathrm{~mm}$ 必要であり, このとき遮 熱コーティング層表面の温度は $1800^{\circ} \mathrm{C}$ 達することがわか った。この他, 同 $\mathrm{CMC}$ 材による内径 $50 \mathrm{~mm}$, 外径 60 $\mathrm{mm}$, 長さ $220 \mathrm{~mm}$ の円筒状の部品を試作し, 部品化プロセ スの検討も進められた.

一方, Fig. 95) に概念を示すセラミックス系多重構造材料 についても開発が進められた. 同材料は, 全体の機械的強度 を担う芯部材料, 高耐熱性や低熱伝導性等により芯部材料を 保護し芯部材料と表面部材料を連結する中間部材料, 拉よび 耐環境性を担保する表面部材料から成って扣り, 特に強度を 担う芯部材料には導電性のある窒化チタン(TiN)を配し，そ のき裂進展に伴ら電気抵抗の変化から破壊検知機能を付与さ せている.芯部材料については, $\mathrm{BN}$ 被覆を施した耐熱 $\mathrm{SiC}$ 繊維と窒化ケイ素 $\left(\mathrm{Si}_{3} \mathrm{~N}_{4}\right)$ マトリックスから成る $\mathrm{CMC}$ を対 象に, マトリックスの緻密化や適切な熱処理による粒界相の 結晶化等により, 室温および $1500^{\circ} \mathrm{C} に$ 执ける 4 点曲げ強度 がそれぞれ $500 \mathrm{MPa}$ 特よび $480 \mathrm{MPa}$, 室温牤よび $1500^{\circ} \mathrm{C}$ 沶ける破壊勒性值がそれぞれ $26.5 \mathrm{MPa} \sqrt{\mathrm{m}}$ 打よび $22 \mathrm{MPa} \sqrt{\mathrm{m}}$ となる, 高強度・高勒性材料が開発された。

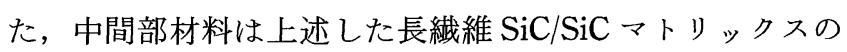
$\mathrm{CMC}$, 表面部材料はアルミナとする多重構造材料の成立性

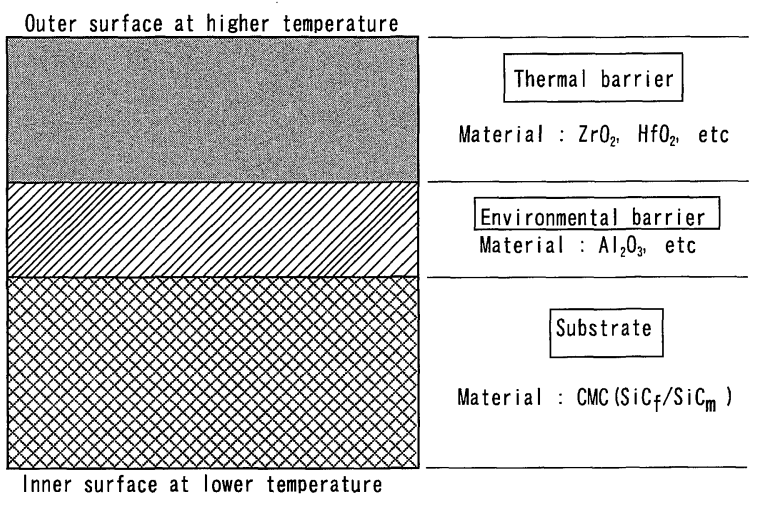

Fig. 8 Conceptual drawing of a coating system for CMC materials.

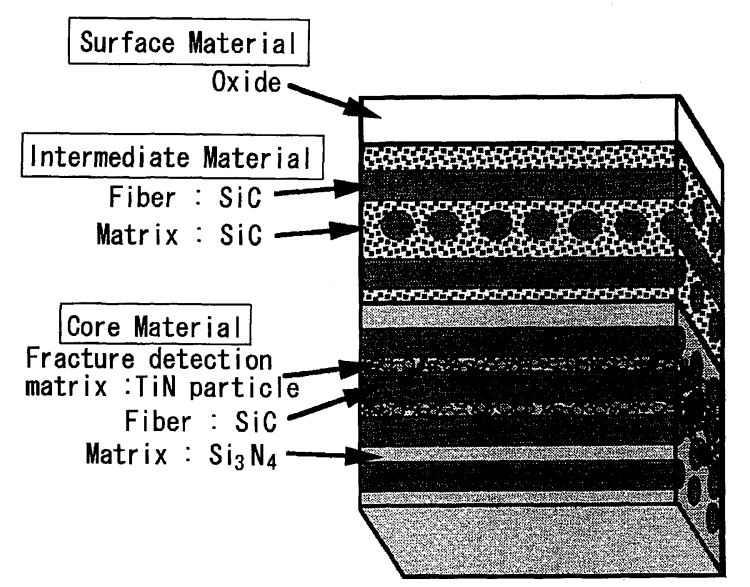

Fig. 9 Conceptual drawing of a multi-structure system of ceramic materials. 
についても明らかにされた。

残された課題は，適用部品形状に則した繊維製織技術を含 も製造技術，耐環境/遮熱コーティングの開発の他，開発材 の長時間耐久性の評価やそれに基つく改良開発等である。

\subsection{5 無冷却あるいは弱冷却部品用三次元織複合材料の 開発}

炭素系複合材料(C/C: Carbon/Carbon Composites) は $500^{\circ} \mathrm{C}$ 以上での耐酸化特性に問題があるものの，他の材料よ り比強度 (二引張強度/密度) が大きく $2000^{\circ} \mathrm{C}$ で強度低下し ないため無冷却部品としての適用が期待される。そこで，無 冷却部品用 $\mathrm{C} / \mathrm{C}$ 和上び弱冷却部品用 $\mathrm{CMC}$ (アルミナ, $\mathrm{SiC}$ ) の両者子対象に，三次元織複合材料の開発が進められた。こ の場合，織維を三次元的に織り上げることにより，層間剥離 を防止でき翼材料に要求される高温強度と勒性が確保でき る. その結果, 三次元織に適した繊維执よび各繊維に適した 安定なマトリックスの選定，緎維配向を可変とする三次元製 織法や最適な複合材化手法の選定等により，目標とした現用
ガスタービン翼材料である $\mathrm{Ni}$ 基超合金 IN738 の900 C K掠 ける比強度を上回る $\mathrm{C} / \mathrm{C}$ 和よび CMC が開発された. 強度 特性の一例として, Fig. 105) 亿 C/C 材の室温大気中ならび

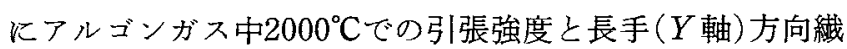
維配向率との関係を示す. 引張強度を担う長手 $(Y$ 軸 $)$ 方向 絩維の配向率とともに強度が向上している。また，アルミナ のCMCについてはキセノンランプ集光加熱式熱衝撃試験を 行ったが，Fig. 115)飞示すように，モノリシックアルミナが 破損する条件に执いても，アルミナ CMC は破損せず，目標 としたもノリシックアルミナ以上の耐熱衝撃特性が得られた.

残された課題は，対象となる大型で複雑形状をした部品の 製織・含浸法の開発，長時間使用可能なコーティング材料の 選定と施工法の開発, 開発したコーティングの耐環境特性の 評価などである。

\subsection{6 高温材料試験評価技術の開発}

上述したよらな超高温材料の開発では，その基本特性の的 確な評価が材料開発へのニーズを明確にする上で必要不可欠

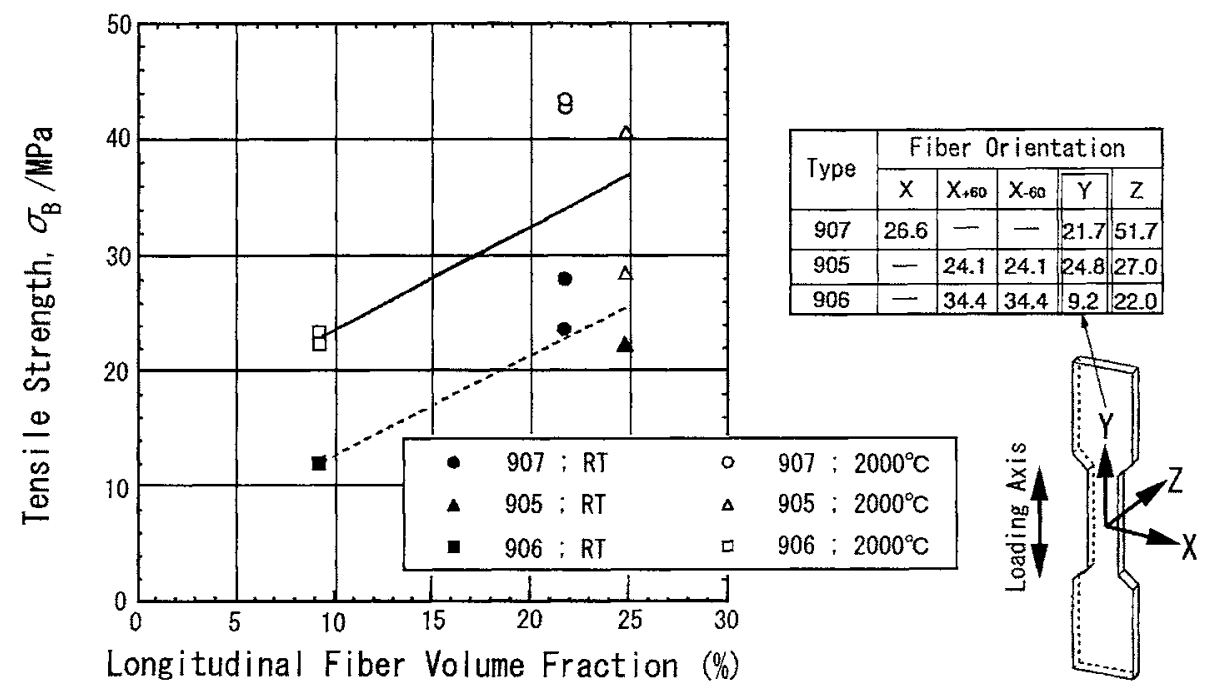

Fig. 10 Relationship between tensile strength and fiber structure in 3-D carbon/carbon composite materials.

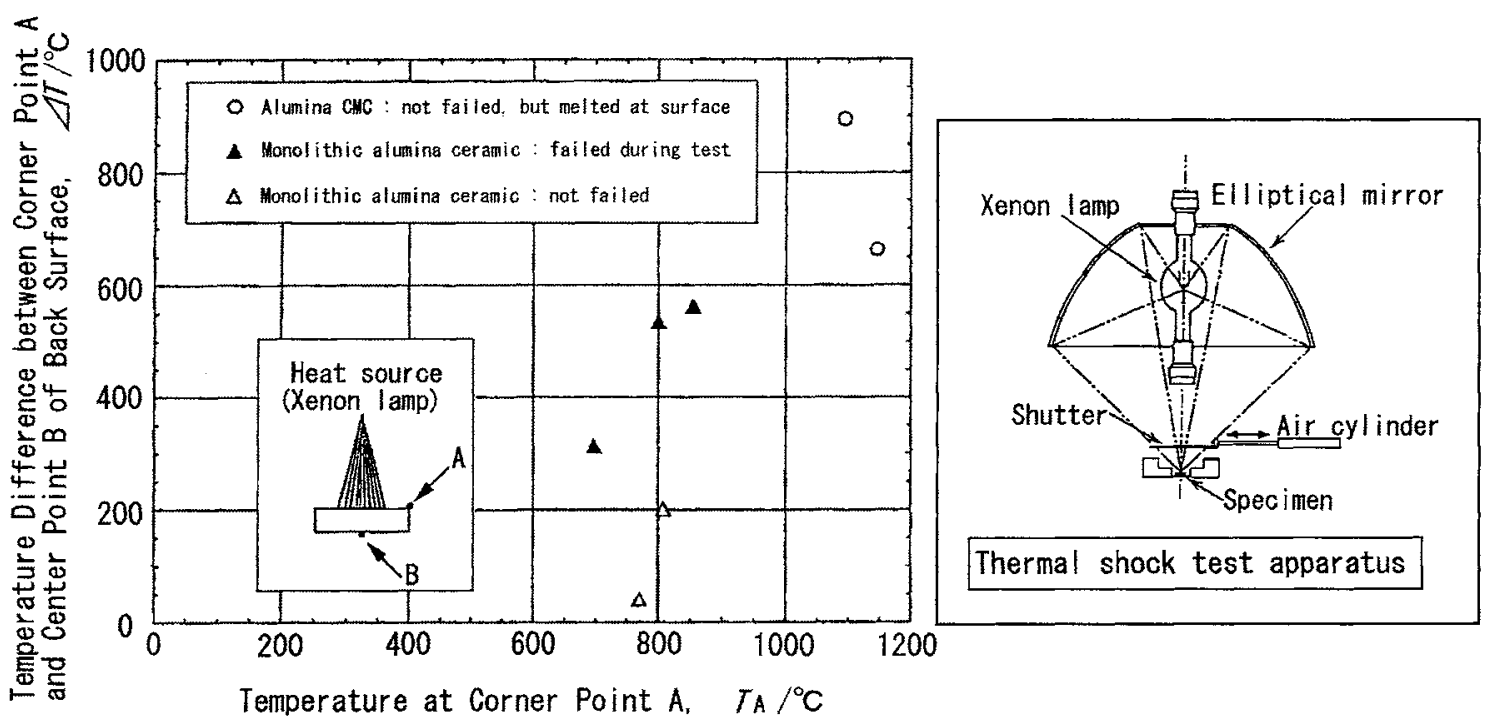

Fig. 11 Relationship between temperature difference and surface temperature in a thermal shock test on alumina materials. 
である、そのような試験評価技術のうち，力学特性について は, 引張, 曲げ, 疲労, クリープなどの材料強度試験が $2000^{\circ} \mathrm{C}$ で可能になった。また，熱物性(熱拡散率, 比熱, 熱膨張率, 放射率等)については，1500 2000 ${ }^{\circ} \mathrm{C}$ 範囲内ま で測定可能な方法が開発された。ささらに，化学特性として， 水蒸気中での高温酸化試験が $1700^{\circ} \mathrm{C}, 0.1 \mathrm{MPa}(1$ 気生) 以下 の条件下で行える技術が開発された．超高温材料の実使用環 境を想定すると，今回開発した高温酸化試験技術の高温・高 圧化，さらには超高温高圧水蒸気環境中での強度特性評価試 験法の開発などが残された課題である。

\section{3 まとめ}

上述したように，WE-NET 計画の第 I 期に和ける水素然 焼タービン用超高温材料の開発に関しては，一部の材料を除 き，注注目標を達成する成果が得られた。しかし，いずれの 材料も素材・試験片レベルでの研究成果であり，今後の実用 化のためには部材・部品化に向けた製造技術の研究開発が必 要である，また，高温材料の基本特性の試験評価技術につい ても, 超高温高圧水蒸気環境中での試験を除き，ほほ確立さ れた.今後は，これらの試験評価技術を用い開発材料の長時 間特性の評価を進め，実用化に向けたデータベースの整備や 信頼性の確保を図るとともに，開発材料の水素燃焼タービン 部品への適用性を的確に判断するため超高温高生水蒸気環境 中での耐環境・強度特性の試験評価技術の開発が必要不可欠 である。

\section{3. 二酸化炭素回収対応クローズド型高効率ガスター ビンプロジェクトの概要}

WE-NET 第 I 期の水素然焼タービンに関する研究開発成 果の早期実現を図るために立ら上げられた，二酸化炭素回収 対応クローズド型高効率ガスタービンのプロジェクトでは, Fig. 123) 《例示するシステム構成に和いて，(1)システム検 討，(2)燃焼制御技術の開発，(3)タ一ビン翼冷却技術の開発，
(4)主要補機類 (高王力比圧縮機, 高温熱交換器, 非凝縮流体 を含む復水器) の開発，(5)超高温材料の開発・評価の各課題 に関し研究開発が進められている。これらの課題の5ら，超 高温材料の開発に関する研究計画は以下の通りである.

(1) TIT $1700^{\circ} \mathrm{C}$ 級の蒸気冷却タービン翼を比較的早期に 実現させるには，候補材として金属系の Ni 基単結晶 $(\mathrm{SC})$ 超 合金が必要になるが，WE-NET 第 I 期で開発された SC 合 金は高温強度上第 2 世代合金と同等であることから，さら に高強度化された第 3 世代合金である国産の TMS-75(Ni$12 \mathrm{Co}-3 \mathrm{Cr}-2 \mathrm{Mo}-6 \mathrm{~W}-6 \mathrm{Al}-6 \mathrm{Ta}-5 \mathrm{Re})$ を巽定し, その高温強 度，熱物性和よび氷蒸気酸化特性を把握する。

（2） SC 合金製の蒸気冷却翼に不可久な遮熱コーティング (TBC) 技術については，その比較的早期の実現のため， WE-NET 第 I 期で提案された気孔率制御 TBC が実用化ま でにはかなり時間を要すると考允られることから，現状技術 を踏まえ, 外表面の耐用温度 $1300^{\circ} \mathrm{C}$, 温度落差 $350^{\circ} \mathrm{C}$ 目標 とする新たな TBC 技術を開発する。

（3） $1700^{\circ} \mathrm{C}$ 級タービン翼の実現を補完し，かつそれ以上 の温度域での適用を可能とする, 非全属系の先進材料として は，WE-NET第 I期で部品化プロセスに見通しが得られた $\mathrm{CMC}\left(\mathrm{SiC}_{\mathrm{f}} / \mathrm{SiC}_{\mathrm{m}}\right)$ 選定し，タービン翼としての部品化まで を視野に入れた研究開発を行う。

（4）材料開発に不可欠な材料評価技術については，WENET 第 $\mathrm{I}$ 期で開発された評価技術に準じて SC 合金の基本 特性を評価するととるに，上記(2)和よび(3)により開発された 遮熱コーティングおよび CMCの耐環境性等の評価技術を開 発する。

\section{4. 超高温材料の耐環境性の重要性}

上述したよらな超高温ガスタービンでは, 通常, 翼等の冷 却には空気よりる伝熱特性の上い水蒸気が用いられることが 多く，また水素を含を然料の燃焼ガス中には必ず水蒸気が存 在するが，材料の耐環境性に関しては, 最近, 水蒸気が看過

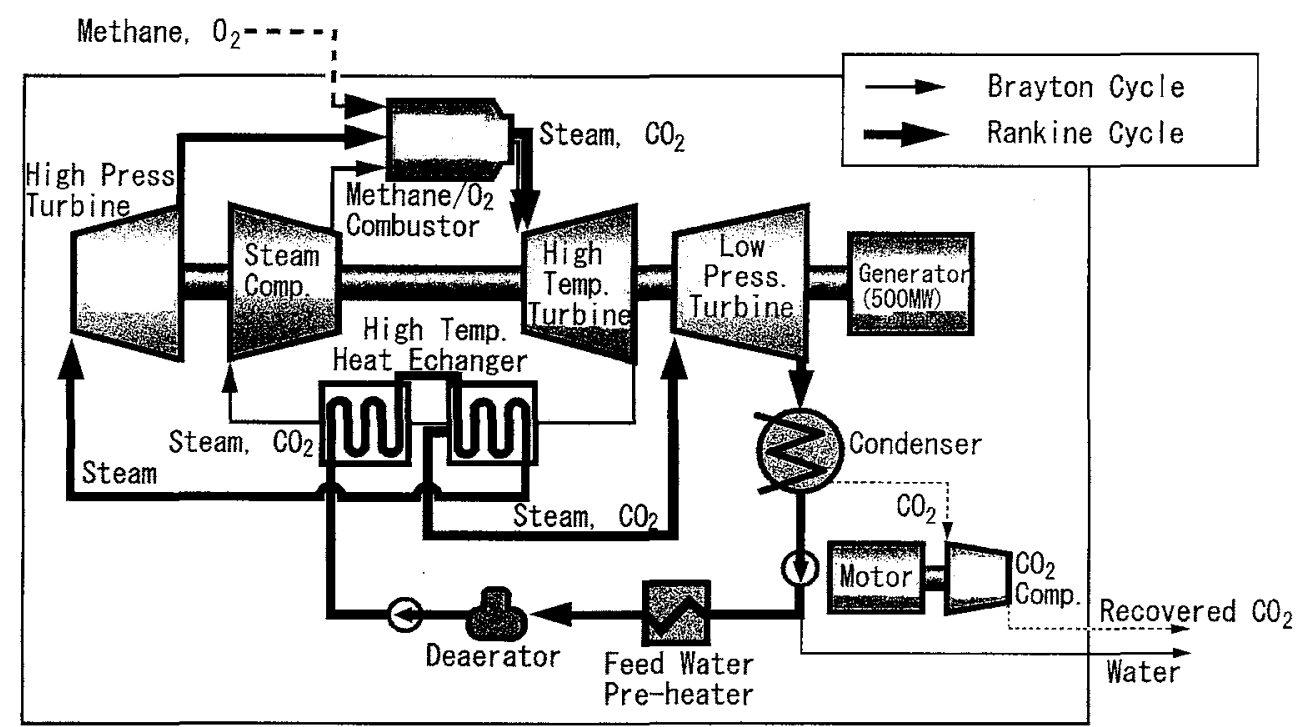

Fig. 12 Schematic diagram showing the advanced carbon dioxide recovery system of a closed-cycle gas turbine. 


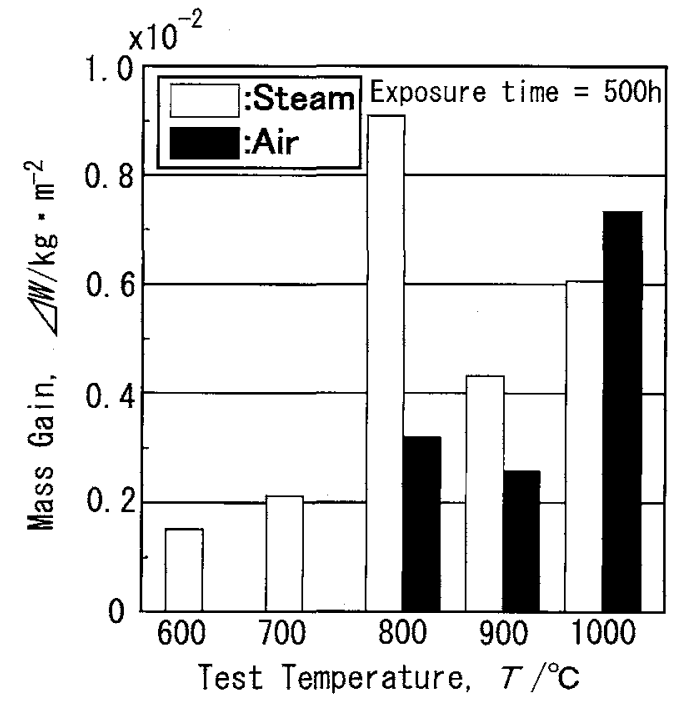

Fig. 13 Mass gain of the CMSX-4 single crystal superalloy in high temperature air and steam environments.

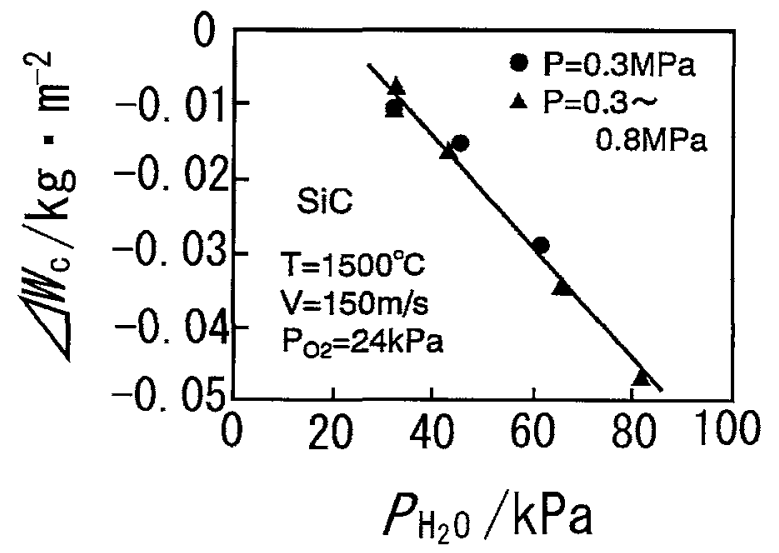

Fig. 14 Effect of partial pressure of steam $\left(P_{\mathrm{H}_{2} \mathrm{O}}\right)$ on the weight loss $\left(\Delta W_{\mathrm{c}}\right)$ of $\mathrm{SiC}$ exposed to high speed flow of high temperature combustion gas.

できない影響を及洁すことが明らかになりつつある。例兄 㤃，蒸気冷却の採用に対し把握して扣く必要がある，Ni 基 超合金の水蒸気酸化特性以ついては，公表された報告は注々 んどない7,8)が，Fig. 13(文献(8)の結果を再構成した図)は WE-NET 第 I 期で得られた CMSX-4 の水蒸気中と大気中 火和ける $500 \mathrm{~h}$ の酸化挙動を比較した結果である.これか ら, 水蒸気中では, 蒸気冷却翼の蒸気通路での平均内面温度 に相当する $800^{\circ} \mathrm{C}$ 亿おいて酸化が最も著しいことがわかる。 ただし，アルミナイジング処理を施せば，800ㄷ和壮る酸 化量は大気中と注涪同等炕なることも明らかてなってい

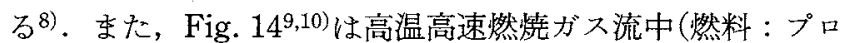
パンガス, 曝露時間 : $10 \mathrm{~h}$ )での炭化ケイ素 $(\mathrm{SiC}) の$ 隇肉現象 を示す結果である。これから， $\mathrm{SiC}$ の減肉(質量減少)に大き な影響を及济す因子は水蒸気分圧であることがるかる。した がって，TBC, CMC 等，水蒸気を含む高温高速燃焼ガス流 中でセラミックスを利用する材料システムに批いては，水蒸
気に対する耐環境性の確保ならびに評価がきわめて重要であ るといえる。

いずれにしても，今後 $\mathrm{TIT} か ゙ 1500^{\circ} \mathrm{C}$ から $1700^{\circ} \mathrm{C}$ 以上に至 るガスタービンの超高温化に伴い，上り一層の高効率化と高 信頼化を図るため, 特にタービン翼用材料には，出来る限り 冷却を軽減し得る耐熱性扣よび燃接ガス (外面) 側と冷却流体 （内面）側の耐環境性の確保，ならびそそれらの適切な評価技 術の開発が不可欠である.

\section{5.おわりに}

これ采で材料技術の進歩・革新が技術的なブレークスルー をもたらした事例は多く，ガスタービンがはじめて実用され た1930年代以降沈括ける TIT の高温化はその好例の一つで ある。現在，わが国では，地球環境保全等のために TIT $1700^{\circ} \mathrm{C}$ 超高温ガスタービン技術の研究開発が国家プ ロジェクトとして推進されている.勿諭, その中で, 超高温 材料技術の開発は最重要課題の一つとなって扣り，ここでは その状況について紹介した．今後のさらなる技術的ブレーク スルーを可能にする超高温材料の登場を大いに期待するとと もに，本稿が多少なりとも関係各位のご参考炕なれば幸いで ある。

文献

1) K. Fukuda: Proc. WE-NET Hydrogen Energy Symposium, New Energy and Industrial Technology Development Organization, (1999), pp. 1-26(in Japanese).

2) T. Hijikata: 19th Report of NEDO Activities, Hydrogen, Alcohol and Biomass Energy Dept., New Energy and Industrial Technology Development Organization (NEDO), (1999), pp. 3156 (in Japanese).

3) T. Hisamatsu: 19th Report of NEDO Activities, Hydrogen, Alcohol and Biomass Energy Dept., New Energy and Industrial Technology Development Organization(NEDO), (1999), pp. 57-80 (in Japanese).

4) Y. Tsukuda, E. Akita, Y. Iwasaki, H. Kawada and K. Tsukagoshi: J. Thermal and Nuclear Power, $51(2000), 685-$ 692 (in Japanese).

5) A. Nitta, T. Ogata, M. Yaguchi and H. Hosokawa: FY1998 Report on Development of Ultra-high Temperature Materials for Hydrogen Combustion Turbine in Subtask 8 of WE-NET Project, New Energy and Industrial Technology Development Organization (NEDO) and Central Research Institute of Electric Power Industry (CRIEPI), (1999) (in Japanese).

6) A. Nitta: Proc. WE-NET Hydrogen Energy Symposium, New Energy and Industrial Technology Development Organization, (1999), pp. 253-262(in Japanese).

7) V. H. Desai, D. C. Tanboli and N. S. Cheruvu: Proc. International Gas Turbine \& Aeroengine Congress \& Exhibition, The American Soc. Mechanical Engineers, (1998), Paper 98-GT587.

8) H. Yoshioka, T. Hino, S. Inagaki and T. Okamura: Proc. of 14th Gas Turbine Fall Meeting, The Gas Turbine Soc. Japan, (1999), pp. 105-110 (in Japanese)

9) I. Yuri, T. Hisamatsu, Y. Etori and T. Yamamoto: Trans. Jpn. Soc. Mech. Eng., 66(2000), 1053-1059 (in Japanese).

10) I. Yuri, T. Hisamatsu, Y. Etori and T. Yamamoto: Proc. International Gas Turbine \& Aeroengine Congress \& Exhibition, The American Soc. Mechanical Engineers, (2000), Paper 2000GT-664. 